\title{
PLANNING PRACTICES OF LOCAL GOVERNMENTS BASED ON THE RESULTS OF AN EMPIRICAL RESEARCH
}

\author{
Sisa Krisztina A. \\ BGF PSZK Institute of Accountancy senior lecturer, PhD student \\ e-mail: sisa.krisztina@pszfb.bgf.hu
}

\begin{abstract}
The purpose of this study is to explore the most important findings of the empirical research conducted amongst local governments of settlements in Hungary, in order to perform a comprehensive analysis on their practices and methods regarding planning. The primary research was conducted in the spring of 2013, with respondent local governments answering relevant questions by submitting a selfadministered questionnaire. The main purpose of the questionnaire survey was to find out whether the involved parties perform actual formal strategic and operative planning activities, and what kind of management planning methods - solutions already working and widespread in the business sector - they apply within the process of planning. In this study, we attempt to conduct a comprehensive analysis on modern planning systems and to appoint the fields that need to be improved, through the results of the questionnaire survey and our own experiences.
\end{abstract}

Keywords: .Planning, Strategic planning, Budget of local government.

\section{Introduction}

Local governments and their related bodies operating under various legal statuses manage large sums and significant assets, therefore this sector has a significant influence on the competitiveness of the whole of the economy. The local public sector has found itself in a critical economic and financial situation on many occasions since the "great transition" of 1990 , which called for the elaboration and actual implementation of various reform measures. It is apparent that local governments of settlements are still either awaiting for or under transformation. Many local studies ${ }^{1}$ have been presented on the economic and financial situation of local governments, revealing as a summary that experts also urge the implementation of reform measures regarding the management of local governments, the financing of the performance of its services and budget planning. Also, the establishment of planning systems allowing for the most accurate determination of the volume of public and generated funds financing the transparency of the performance of their public services, duties and the quality of the administration, are all in the interest of the national economy as well. The sector is characterized by the complexity and slowness of information flow, the inaccurate planning of cost allocation (expenditures), the poor transparency of the financing of tasks, and the belated or inappropriate decision making of the leadership.

The objective of business administration on a sub-sover- eign governmental level can be described by the " $3 \mathrm{E}$ " paradigm. According to this, public services must be effective, efficient and economic. Nowadays these "threefold of goals" have been completed with the issue of quality, or more precisely with the expectation of "quality public services". The question is, how much do the currently applied planning system support the fulfilment of these objectives? Experts and those who are directly involved agree that the planning system must be reformed and improved, along with the elements of the procedure and the methods of planning. We believe that by the careful and targeted selection of the tools offered by the NPM (New Public Management) school or public management model - on account of its practicality - it is possible to select the appropriate management tools and methods, the application of which is justified on the level of local governments, and which also contribute to the implementation of economic, efficient, effective and quality public services.

These strategic and operative analysing-planning methods which are applied within the frame of controlling, and are already successfully applied by the private sector allow for the more efficient operation of these processes, and also enable the achievement of the set objectives regarding the sector of local governments. It is also supported by the favourable change causing the reformation of the accounting information system as the fundamental basis of information for planning, by introducing a performance-driven approach in the budgetary accounting system as from 2014.

For further details, see the studies of Lóránt [2010], Vígvári [2009, 2011], Báger-Vígvári [2007]. 


\section{Literature review}

\subsection{Concepts on planning within the public sector}

For the concept of planning, there is no definition found in literature independent from history - political culture - and theoretical planning schools, which would hold in all historical periods and political systems. In general, definitions regarding planning narrow down the concept by considering it to be equal with the preparation of the budget. [László, 1994; Koháriné, 2011; Farkas (ed), 2004; Csanádi-Tóth, 2002]. László understands planning as a decisive element of the preparation of the budget. The planning activities of those who are operating from a budget include the construction of the budget, during which the transformed plan (or budget) prepared by bureaucrats, and disputed by all parties of the negotiation process is approved by the political body entitled to make a decision [László, 1994].

We believe that we must not consider the planning of the budget and planning to be equal, since the budget actually refers to a - usually annual - financial plan which is prepared annually, while the referenced literature discusses the budget as an umbrella term, which also includes the long-term planning duties of local governments. Therefore the economic program as a long-term plan is discussed within the frame of budgetary planning, as part of the plan. Similarly to the concept of planning management, it is also suggested to separate long-term planning from the process of preparing the annual plan (budget), of course both fields of planning are included in the concept of the planning process.

The following definition describes planning in a more general and comprehensive way: planning includes the analysis of the external environment, internal features and the exploration of potential development paths for local governments and their institutions, furthermore it also enables the sharing of information and the reconciliation of interests between participants [Báger ed., 2010]. This definition is close to the business approach of planning in terms of considering the analysis of the internal features and abilities of the environment and the organization to be part of the planning process, and also it draws the attention on the cooperation that is realized between those who take part in the planning process, which should result in a plan representing the various interests of different stakeholders.

New elements of the concept of planning emerge in the next definition, which include the interpretation of planning as a structured process, and emphasizing it as a tool for control, thus positioning planning as a management function - similar to the definition of planning used in the private sector. Public planning is the execution of democratic will without intentions on limiting the behaviour and capacity of members of the society, instead, by the means of planning, it is possible to get closer to the efficient implementation of the public will, and to facilitate social-economic development. Planning is a well-structured instrumental method of success-oriented social actions, an explicit tool for control [Faragó, 2001].

Literature referred so far on planning focus on the process-nature of planning, and consider the process to be final with the completion of the plan document, as the fulfilment of the main purpose of planning. We believe that the planning of local governments - just as in case of the business sector - cannot be limited to the preparation process of plans only, since one of the key indicators of the success of planning is the effective implementation of plans, and its power to support measures, management decisions and the performance of everyday tasks and actions, therefore the implementation of plans must also be analysed by exploring the differences between estimations and the completion of estimations and their related reporting processes, along with the elaboration of a scheme to measure the efficiency and effectiveness of the goals set during planning and in plans. ${ }^{2}$

Financial planning by local governments in Hungary is traditionally associated with budgeting. All initiatives aiming to reform the concept and methodology originate in the public management reform trends. The most reknown public sector reform concept is the New Public Management (NPM) movement. Several theoretical schools are represented among NPM-reforms that consider the adoption of management practices and methods for the public sector as a solution for the malfunctions of state and public administration. These schools reveal the outdated elements of planning, while draw attention to areas in need of reforms.

The article of Hood in 1991 [Hood, 1991] called my attention on the fact, that the expanding NPM offers non less than a universal solution for public services, however the author have already foreseen several sources for internal tensions which actually emerge later. The NPM doctrine announced the adaptability of the methods of the private sector to fit the public sector as well, and also proclaimed a more efficient control over processes, the priority of the market as an allocation mechanism and the role-shift of the government (as "it should govern, and not execute"). The reasons for its expansion include political-ideological factors, fiscal aspects, and the demand of citizens for improved public services, while the primarily cause for becoming a global phenomenon is considered to be the cultural-scientific dumping of the pioneering Anglo-Saxon countries, which was further convinced by the fact that global organizations also recommend this radical proposal [for details see: László, 2012].

The ideology and the evaluation of public management reforms announced and/or implemented accordingly is a recurring element in all of my studies in the subject. The lessons learned from these evaluations: 1) the importance

\footnotetext{
${ }^{2}$ On the other hand, the analytic examination of the planning activity cannot be considered independent from other leadership sub-systems, on account of the complex nature of the activity.
} 
of the local context: the identity of slogans resulted in completely different solutions in case of countries with differing traditions and practices [Pollitt and Bouckaert, 2011]; 2) the practical application of the basic axioms did not work out as expected ${ }^{3}$. Even the pioneering NPM countries such as Great-Britain, Australia or New-Zealand reconsidered their approach on public services in light of the results [Warner, 2012]. Dunleavy and his co-authors (2006) report on the termination and reversing of a number of key factors in case of the above pioneering countries, and Warner [2008, 2010] also discusses the trends on reversing outsourcing and privatisation, and the expansion of mixed services. Similarly, Hall [2012] investigates how public services are being „executed by the government" and the reasons for it; 3 ) the recovering of this task will result in governments taking up the role of the executor, instead of conveniently being the organizer of services. It allows for the control over a great share of the local economy, however it also brings back the administration-related problems, which they have been able to get rid of by outsourcing them: on account of the traditional budgetary approach and the political influence, it is impossible to implement an economic-oriented approach on tasks (e.g.: effectiveness, efficiency, economy, financing, service quality). According to what has been discussed regarding the local society, the solution lies in the development of the management activities of self-governments and its institutions - especially focusing on the field of strategic management (strategic thinking) and the establishment of a controlling system, which could be applied both in case of its own institutions, and external service providers, in order to ensure value-adding public services.

\section{The importance of planning}

As regards planning, future becomes the moving force of actions and decisions. The importance of planning in the public sector is probably even greater than in the private sector, since the players of the public sector perform their duties from public funds, providing their services for the "customers", members of the society. The outstanding importance of planning in the public sector might be explained by the following reasons:

- Budgetary authorities perform their public services and satisfy social public needs out of the payments of citizens, paid under various claims. Tax-paying citizens - as a rightful claim - want to see through the kind of compensations they receive in exchange for their payments (social control). The "state" can only give an accurate answer to this question, if an accurate budget (plan) is made on the public services to be performed (expenditure requisites), and their financial coverage (financing sources). The state must become accountable. In order for this, we must be able to measure public services (output and outcome), and the practical implementation of budget planning is also required, by applying the most appropriate planning method during the process of planning.

- The state and its various apparatuses react slowly to the changes of the economic environment and to the impulses of the market's supply-demand relations, therefore the fulfilment of public services and the financing system must be thought through as accurately as possible, with foresight and by the reduction of risks and uncertainties to a minimum level, all of which would be impossible to implement without an effective planning process. Without a carefully elaborated efficient planning also supported from a professional aspect, it is impossible to create an effective budget.

Further arguments supporting the necessity of planning are "sector neutral". The future motivates management decisions through planning, the uncertainties and risks regarding the operation might be reduced by an accurate, well-thought and formalized planning, as planning marks the path of development for a company, which enables the implementation of a more effective (goal-driven), successful operation.

According to Faragó, the major characteristics of planning within the public sector of a modern market economy are the followings:

- "multi-levelled and the involvement of several players (the system is not formed by only the basic conflicts of economy);

- Presence of two directions (top-down and bottom-up at the same time);

- It accepts the necessity of governmental intervention (from outside, top-down) (for the long-term interests of the nation);

- Value-pluralism;

- Aspires to conform to the level of the society's knowledge (scientific, rational), however it is also restricted by the volume and type of the available information;

- Dual: it partially assists (generates), and partially limits the private sector

- And it is determined by politics." [Faragó, 1997].

Planning establishes contact between the local government and its environment. We must prepare for the anticipated changes and challenges of the environment with the help of planning. Legislative environment as the "explanation variable" plays an outstanding role considering the elements of the environment, since it influences and explains directly the basic conditions of the operation of the planning system as a "dependant variable". Therefore, prior to the comprehensive introduction of the planning system it is recommended to briefly review the legislative environment.

\footnotetext{
${ }^{3}$ In Hungary, privatisation and liberalisation were accompanied by the process of denationalization, during which the ability of the state to regulate the market was shaken, the recovery of which is indispensable, and as a recommendation, according to the neoweber state model (NWS).
} 


\subsection{Legislative framework of planning, operation of designing system}

The framework and essential regulations regarding planning activities of local governments are regulated in Hungary by laws and related government regulations. The basic and decisive prescriptions regarding planning are specified by the law on public finances (hereinafter referred to as Áhtv.) $)^{4}$ and the law about the local self-governments of Hungary (hereinafter referred to as Ötv. $)^{5}$. Regulations regarding the process of planning generally focus on the planning of the annual budget, while duties on planning for a mid or long term are barely included in the legislation.

The general objectives of planning are described by the 12 . $\S(1)$ of Áhtv., "the purpose of planning is to ensure that the approval of the expected revenues are supported from the aspect of economics, and estimated expenditures are only determined to an extent necessary for the appropriate performance of public services". The legislation also declares that new public services can only be created or undertaken, when the necessary financial resources are available for its completion. In case financial resources become unavailable throughout planning, the termination of the public service must be executed.

\subsubsection{Regulations affecting long-term planning}

According to the current legislative environment, the preparation of long-term plans is required in case of settlement instruments, settlement development concepts and plans, and economic programs adjusted to political terms. Certain sectoral legislations might also prescribe obligations on the preparation of long-term programs and plans, such as environmental programs, rural development or touristic concepts etc. According to the regulations of the Ötv., local governments must determine their own economic program. The leadership of the local government formed after the elections records its long-term development concepts in an economic program and development plan, based on the results and experiences of the previous political term, its perspectives on the future, and own objectives set out during the campaign. Within the terms of the Ötv., the time interval of an economic program must cover at least one political term (which is 4 years in Hungary currently), though it might be longer than that. In this sense, the economic program might fulfil the role of a comprehensive long-term plan, if it includes the main objectives, tools, achievement methods and strategic plan elements of fields of activities, which are of strategic importance. Nevertheless, neither the Ötv., nor the Áhtv. contains mandatory obligations on the structure, content, form and validity of the economic program, therefore local governments determine their long term objectives and the criteria and toolkit of the implementation themselves. The content of economic programs are not regulated in details by legislation, instead there is a general statement: "the economic plan and development plan determines the objectives and tasks which serve the purpose of ensuring the services to be performed by the local government and the improvement of their quality, if possible in accordance with the extent of the budget of the local government, by thoroughly considering the peculiarities of the local society, environment and economy" (Ötv. 116.§(3). Further specifications of the Ötv. declare that the economic program must be elaborated in accordance with the regional development concepts of the county, and special focus must be placed on development concepts regarding the ensuring of public services and the improvement of their quality. This is a general and comprehensive objective, the implementation of which depends on local governments, thus allowing for a great deal of freedom for local governments regarding the completion of their strategic planning duties. There are no other obligations or guidelines specified by legislation regarding the preparation of an economic program.

The purpose of an economic program - as a long-term, comprehensive plan - is to be the foundation of the annual budget concept and annual budget to be prepared subsequently. An economic program can only fulfil the role of a comprehensive strategic plan, if its objectives, tools and programs are also built in the annual budget, and the government is able to follow the selected "track" within the program in order to achieve its objectives. The economic program has to be modified and updated in exceptional cases - such as an unexpected modification in a regulation, or other changes within the environment -, since plans are active or passive tools for adjusting to the changes of the environment.

\subsubsection{Mid-term (tactical) planning}

Mid-term, or so-called tactical action plans create the direct and measurable relation between strategic and annual plans throughout the planning process of companies. Regarding the mid-term planning of local governments, the Áhtv. declares it briefly that at latest until the regulation and decision on the budget is approved, and within the frame of a decision, local governments have to perform an assessment annually on the amount of their own revenues defined by the legislation issued under the authority of the Stability law, and also on the amount of its expenditures that are derived from operations generating debt according to the Stability law, estimated for the three years that follow the financial year.

\subsubsection{Short-term planning: \\ The concept of the budget and the annual budget}

The preparation of draft regulations on the budget of local governments requires a continuous preparation and planning work. The economic program prepared at the beginning of

\footnotetext{
${ }^{4}$ The current legislation in force is the act CXCV. of 2011. on public finances, and the related government regulation number 368/2011. (XII.31.) on the execution of the law on public finances.

${ }^{5}$ The current legislation in force is the act CLXXXIX. of 2011. on the local self-governments of Hungary.
} 
the political term (election) is one of the foundations of the draft regulations on the budget, the other one is the budget concept prepared annually under the direction of the notary. The concept on the budget is prepared by the notary and the planning unit under the direction of the notary, taking into account the bill on the central budget, the expected economic policy of the government and its macro-economic forecasts, the planned objectives of the economic program, foreseen revenues, undertakings and other payment obligations. Leaders of institutions overseen by the local government have to be involved in this planning process, which means that institution leaders must be informed about the planned guidelines of the central budget, about planning instructions and principles on the performance of services of governments, and also on the regulation of resources. After that, local governments determine the range of numerical and textual information they require from institutions themselves, for the elaboration of the concept. Actual calculations have to be performed within the budget concept regarding the expected resources of revenues and the tasks of self-governments (expenditures), practically in a structure corresponding to the revenue and expenditure elements of the budget. The actual structure and content of the concept is not specified by the law. During the process of composing the concept, the mayor asks for the opinion of bodies on the draft concept, with the opinion of the financial body being of utmost importance considering the financial feasibility and sustainability of the concept. The body of representatives is empowered to approve the draft budget concept which already includes the opinion of bodies, and which is implemented in the form of a decision. The exact form and content of the decision made by the body of representatives is not regulated by legislation. The first stage of the budget planning process is completed with the approval of the budget concept, which results in a document that will serve as the actual foundation of the planning of the budget.

Legislations in force are characterized by the dominance of regulations on the preparation of the annual budget. The tasks related to the preparation of the annual budget of local governments are clearly regulated by the Ötv., Áhtv., and the government regulation on the execution of the law on public finances. The annual budget is the foundation of the administration of local governments, which is part of the government's budget. The budget represents an actual fund, which serves the purpose of financing defined objectives. The budget is also a financial plan, which is driven by the future and includes uncertainties and risks as well, on account of its nature. Furthermore, the budget is a legal document which is approved by a legitimate political body, and it expresses and exercises public policy objectives [Györffi-Vígvári, 2009]. In a political sense, the budget is the program of the government, from the aspect of public policies, it is the classification of all governmental tasks, and in financial terms, it is a tool for harmonizing expenditure claims with revenue opportunities [Magyary, 1923. quoted by: Sivák-Vígvári, 2012].
Áhtv. defines the budget as a document, which contains the appropriated value of budgetary revenues being realized in the financial year (revenue estimates) and budgetary expenses (expenditure estimates). (Áhtv.4.§(2)) The budget is also regarded as a plan by the legislation, which includes the estimated, thus the planned amounts of expenditures and revenues for the upcoming year. The second, final step of budget planning is the preparation of the annual budget and its approval in the form of a regulation.

A budget in general is prepared annually, which means that the budget is usually valid for a calendar year. The annual budget is the financial foundation of the performance of mandatory and volunteered services throughout the administration. A two-levelled planning is typical in case of the budget planning of local governments. First, the joint budget of the government and its institutions has to be prepared, which is determined by the local government, in the form of a regulation on the budget, and second, a budget will also be prepared on the elements of the government and its institutions. Vígvári has a different interpretation of the two levels of the budget planning process, accordingly, the first level of planning is the central level, where the planning of the financial resources "to be spent" in the financial year is implemented, being available in the form of a governmental fund for the performance of mandatory services of local governments [Vígvári, 2002]. The second level is the actual planning of the budget of local governments [Vígvári, 2002].

The initial foundations of the annual budget planning are the objectives of the economic program for the financial year, the decision of the body of representatives on the budget concept, and the budget law including the announced central budget. The planning process of the budget is a multi-stage process with several players involved. The major planning processes are: tasks regarding the preparation of the budget, the construction of the budget, the submission of the budget to the body of representatives and its approval, the elaboration of the regulation on the budget. ${ }^{6}$

Besides the preparation of the annual budget plan, the Áhtv. includes a brief note on the obligation of preparing a liquidity plan, that local governments are obliged to prepare a liquidity plan on the scheduling of the reception of revenues and the completion of expenditures. However there are no legal instructions on the structure, content and frequency of preparing a liquidity plan. Other obligations on the preparation of short term plans are also not regulated by the referred legislation.

\section{Materials and methods}

\subsection{Planning and data collection}

We have conducted primary researches as well, in order to complement the theoretical information gathered during the secondary research activities, and also to confirm our previ-

${ }^{6}$ The process and procedure of the planning of the annual budget is described in details for example by Farkas [ed.], 2004. 
ously drawn up hypotheses. The primary research has been implemented by the means of a scheduled empirical research based on quantitative data collection. The data collection has been conducted with surveying, which is considered to be the most common instrument within social sciences for gathering primary information. The registration of data did not cover the entirety of the population. Errors within data collection can be grouped in two large categories:

- sampling errors

- non-sampling errors [Hunyadi-Vita, 2002].

In case of the latter there is no available exact mathematical tool, which would be able to filter its impacts, yet its size cannot be ignored [Hunyadi-Vita, 2002]. Such errors during the research include the distorting effect of pessimism (respondents tend to underrate their own performance), the effect of vanity (respondents paint a more favourable picture of the performance of the organization they directly control and supervise than it actually is - even due to personal reasons) [Szücs, 2002].

In case of the former, the appropriate planning of sampling, and the achievement of the required preciseness ensures the minimization of the impact.

Our task regarding the planning of data collection was to minimize the impacts of the two types of errors at the same time. We aspired to carry out a simple random sampling, and also to make the sample size as large as possible.

Based on the planned sampling method, we have tried to deliver the self-completed questionnaires to respondents through a variety of channels. We have contacted several governmental associations, namely the TÖOSZ (national association of the governments of settlements), MJVSZ (the association of towns with county rights), and BÖSZ (the association of the Budapest governments). These organizations have proven to be quite helpful, and forwarded the questionnaires to governments on our request.

It was difficult to complete and collect the questionnaires, therefore we have included college students in the research as well, and we have personally called the associates of the involved governments in order to ask them to fill out the questionnaire. The completion of the questionnaire occurred via telephone, e-mail and in case of the research amongst students, by personal interviews. The data collection lasted for several months, as we needed to re-send the questionnaire, in order to increase the number of the filled out questionnaires - thus increasing the size of the sample. There was a total number of 600 questionnaires sent out, out of which we have been able to make use of 64 valid forms within our empirical research.

The empirical research has been conducted with a sample consisting of 64 valid elements. Sample selection was implemented by the method of simple random sampling, which supports effectively the creation of an independent and representative sample. Local governments were categorised as specified by the Act on Local governments, with the following categories: capital districts, towns with municipal rights, towns and villages (large villages). Local governments of villages and large villages represented the greatest share, 37,5\% within the sample, which is parallel to the distribution of local governments in Hungary according to their type. The proportion of towns within the sample of local governments was $29,7 \%$, and $20,3 \%$ in case of capital districts, while the lowest proportion with $12,5 \%$ was represented by the local governments of towns with municipal rights.

The category types of local governments also reflect on the size of their organization. However we must also consider that a particular type of local government might appear in multiple categories based on the number of its staff regarding the size of the organization, therefore we have performed the grouping of local governments according to their size based on the number of staff, instead of defining size categories by the type. It means that the number of staff of the institution exceeded 1000 employees only in case of "large" local governments: capital districts and towns with municipal rights. Throughout the empiric research, local governments with a staff number less than 50 were considered to be the smallest, while the largest ones were local governments with a staff number exceeding 1000 . It must be noted that during the analyses there was only 1 local government with a number of staff over 3000 included in the sample, therefore this size category was merged into the category of 1000-2999 employees. As a result, local governments involved in the study were analysed by rendering them in 4 size categories. The four size categories were named "micro" (less than 50), "small" (50-199), "medium" (200-999) and "large" (more than 1000).

\subsection{Statistical method}

The study is supported by both primary and secondary research as well. Primary sources of data were provided by questionnaires sent to involved parties (financial executives, planning coordinators, notaries). The questionnaire consists of several groups, including mostly multiple-choice, relevant questions. In this present study, we aspire to summarize the typical characteristics regarding the current system of planning and planning practices. Now we have a variety of statistical analysis methods available for the analysis of databases. The actual application of these various statistical analysis methods were complicated by the fact that the data subject of the analysis are in general quality-type data measureable on a nominal and ordinal scale as well. As a consequence, descriptive statistical analyses prevail throughout the study, while with the help of statistical independence analysis we also attempted to explore causal links. Based on the element number of the sample, it is considered to be a small sample, therefore when selecting further statistical methods we had to prefer statistical methods applicable on a small sample. Considering these criteria and characteristics, the available data was analysed with an independence analysis implemented by a Chi-squared test, a two-sample T-test, a variance analysis and cluster analysis. For performing an analysis on the data, we have applied a computer-assisted data procession with the SPSS data processing software. 


\section{Results}

\subsection{Long-term - strategic - planning practices}

First we wanted to understand the purposes local governments aspire to achieve with planning. The results of the analysis indicate that in most cases ( $37 \%$ in general) they are fulfilling their legal obligations with planning. The second highest result $-29 \%$ in average - was achieved by the answer that they prepare various plans for their own goals and interests. Other external factors also represent a significant share, with $16 \%$ in case of supervisory authorities, and $15 \%$ in case of obligations towards the European Union. If we break motivational factors into three categories, which are own -internal- interests, external force (the total share of legal obligations, supervisory authorities and EU obligations) and other motivations, the picture becomes significantly worse, since the total average share of external obligations when preparing a plan reaches $68 \%$, compared to which the $29 \%$ proportion of internal self-interest seems insignificant. It was interesting to examine the motivations of local governments for planning separately by their size. Self-interest represents a surprisingly high proportion $(42 \%)$ in case of micro governments, while the fulfilment of legal obligations was selected mostly in the category of small governments (with 48\%), and large governments were only able to achieve the second position in relation to the same factor, with $40 \%$. The results lead us to the conclusion that the application of a strategic and management approach is less typical with leaders of local governments.

Besides the annual budget, the questionnaire includes the most typical types of plans applied in business. The various plans applied in the business sector can all be adapted to this sector as well. Naturally when applying them we must take into account the peculiarities of the administration of governments, financing and the accounting information system. Answers had to be submitted in the form of yes or no questions about the types of plans that are being prepared in practice. In case of complex planning activities, the following plans are suggested to be prepared:

- long-term plans (joint strategic plans on the level of the government and its institutions, sectoral and functional strategic plans)

- annual budget as the preliminary financial plan

- secondary financial plans (liquidity plan, cash flow)

- other plans (resource plans, risk assessment, other).

Detailed results are presented in the related attachment (number 1.) of the study.

Respondents indeed implement long-term planning, 87,5\% of them prepare joint strategic plans on the level of the government and its institutions, which they consider to be equal with an economic program. When observing the other levels of long-term plans, we receive less favourable results, $50 \%$ of respondents prepare sectoral, and only 34,4 percent prepares functional strategic plans. The results are similar in case of examining the answers based on the sizes (figure 1. demonstrates the results in details). The proportion of those who prepare joint strategies are between 79 and 94 percent in case of all size categories. Sectoral strategic plans are most frequently constructed by large local governments (with $87 \%$ ), and micro governments are the ones less likely to prepare it, with a proportion of 21 percent. The existence of functional strategies are also the lowest in this case - similarly to the aggregated results, their share is between 21 and 47 percent.

The next "yes or no" question was about whether local governments involved in the study perform formalized strategic planning. The majority of respondents, 37 out of local

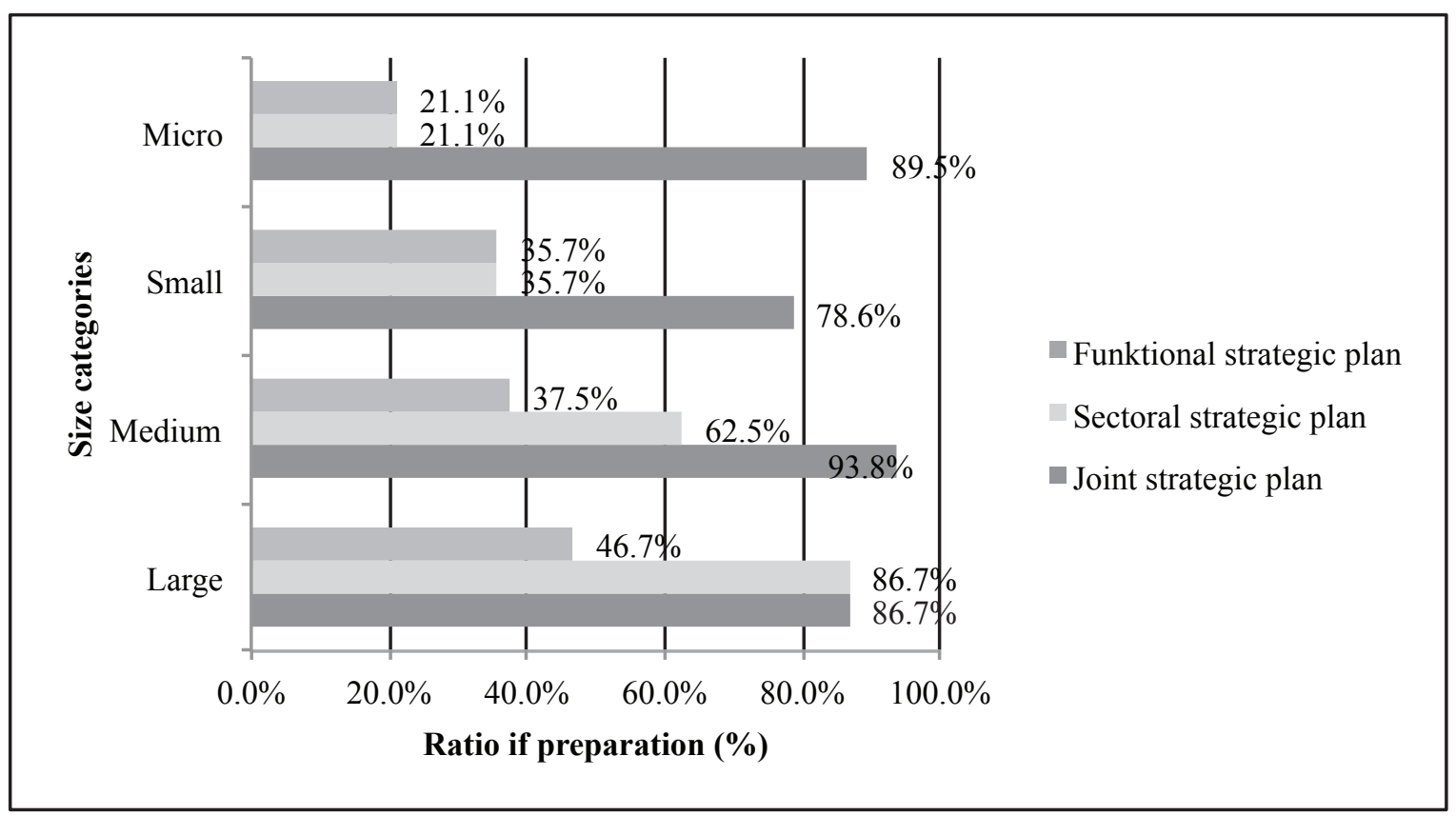

Figure 1. Relation between the type of government and long-term planning

Source: own edition (2013) 


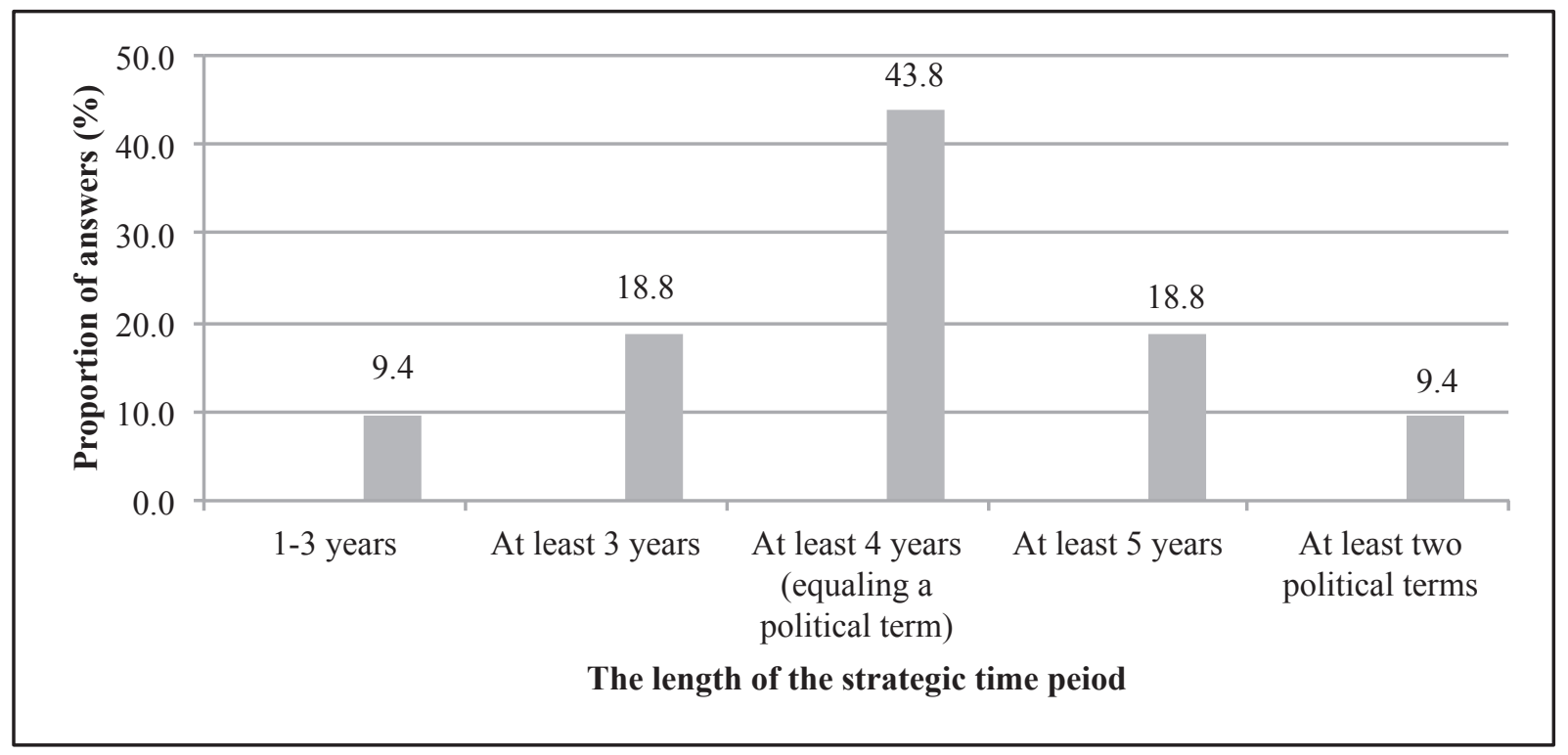

Figure 2. "Strategic periods" according to respondents

Source: own edition (2013)

governments $(57,81 \%)$ admits to implement formalized strategic planning, however the proportion of local governments to answer with "no" slightly exceeded the proportion of those who said "yes" in case of micro and small sized local governments $(52,63 \%$ of micro self-governments, and 57,14\% of small self-governments). Furthermore, $55,6 \%$ of the remaining 27 local governments who do not apply formalized strategic planning believes that its realization in the future is reasonable. I believe that this ratio reflects a positive attitude regarding the future application of strategic planning.

Nevertheless, the high proportion of the existence of formalized planning contradicts the approach of respondents on strategic periods.

$43,8 \%$ of respondents believe that a political term (4 years in Hungary) is considered to be a strategic time period, and only $9,4 \%$ of them agree that strategic planning must cover a period that lasts for the length of at least two political terms. Considering that political decisions have long-term effects in general, it is important that planning is not only about "tomorrow", but it should bear in mind the wellbeing of future generations as well. Further consequences of a short-term approach is that when the current leaders - elected representatives and officers - are characterized by short-term thinking and enforcement of interests, their chances to be re-elected decrease. Now when the management of a town is replaced every 4 years, it is impossible to establish a future that is supported by strategic planning as well.

Naturally the examination of the existence of long-term planning cannot be based on solely these questions, since actual strategic planning is not limited exclusively to the preparation of strategic plan documents. Monitoring activities, continuous reporting, feedback and the revision of strategic plans and their necessary modifications all form an integral part of the planning process. Strategic plans supporting efficient op- eration in the long-term must be underpinned by the application of strategic analysis and planning methods which are already applied in the business sector and could be successfully adapted to local governments as well, otherwise strategic plans mean nothing but romantic, impractical concepts and promises which are impossible to keep for the members of the society, instead of well-designed plans which are mathematically founded as well, and could be realized successfully in the future.

We attempted to assess the proliferation and frequency of the application of the most popular methods by governments, which can be applied during the elaboration of the strategy, with the help of a scale ranging from one to five. The values of the scale were: 1 - we have never heard about this method; 2 - we are familiar with it, but we have not applied it yet; 3 - we have applied it, but it did not work; 4 - we apply it occasionally; 5 - we apply it frequently. The results are demonstrated by figure 3 .

The results of the questionnaire survey confirmed our preliminary hypothesis, which is that involved parties are completely unfamiliar with the strategic planning-analysing methods which are most frequently applied in the business sector (PEST analysis, Porter models, ABC analyses, GAP analysis, Scenario planning, LEAP, EFQM, value-chain analysis, external-internal factor evaluation matrix), or even if they have previously heard about a very few of the methods, they have never actually applied them in practice (such as BSC analyses, Portfolio method, TQM, Benchmark analysis). The most common method was the "SWOT" analysis with its $20,3 \%$ ratio. Table 1 . demonstrates that the majority of analysed governments $(57,8 \%)$ lack the implementation of strategic monitoring. It means that they do not track the completion of strategic goals through the measurement of indicators. This result also confirms that the elaboration of a 


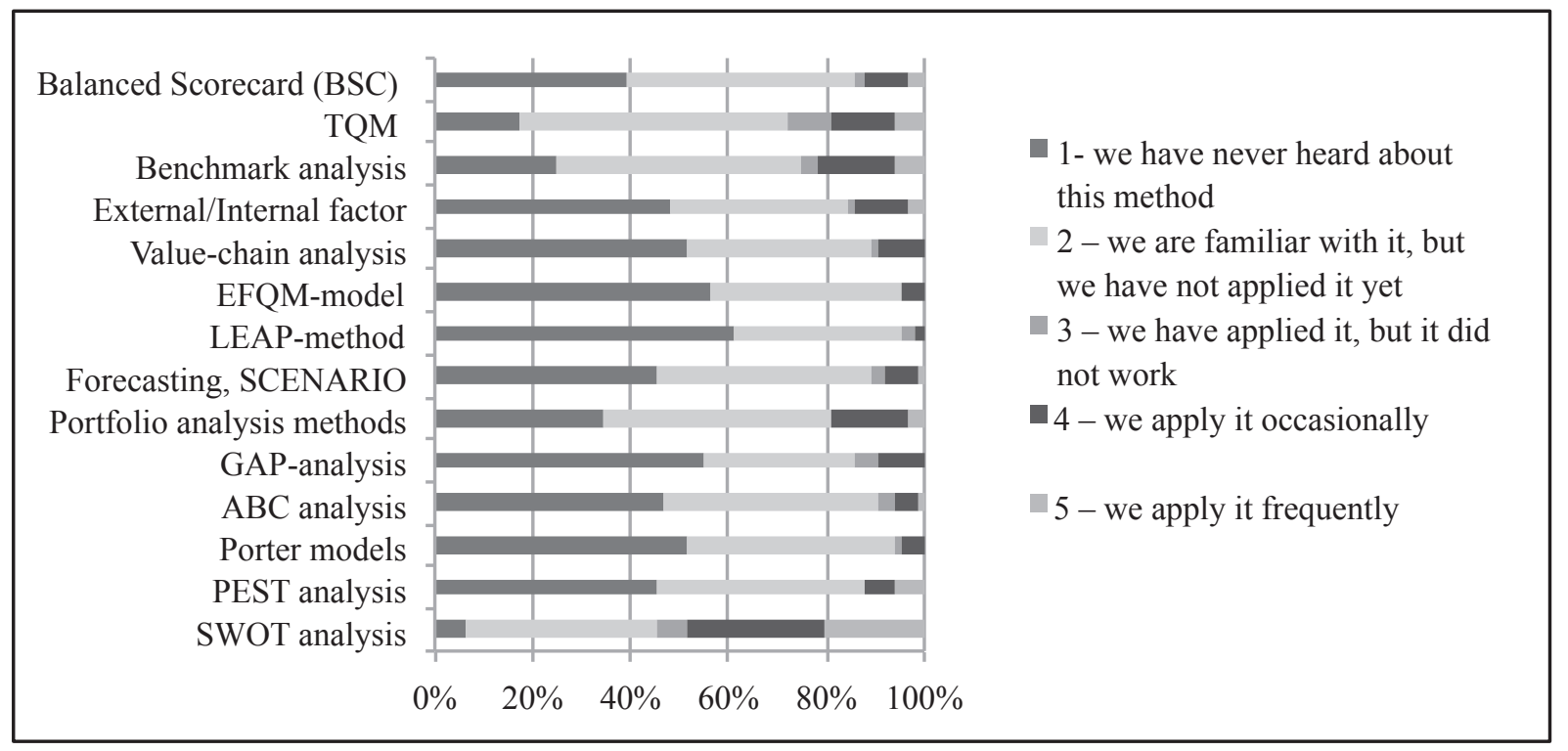

Figure 3. Existence of strategic planning-analysing methods

Source: own edition (2013)

Table 1. Existence of the tracking of strategic plans

\begin{tabular}{|c|c|c|c|}
\hline \multicolumn{2}{|c|}{} & $\begin{array}{c}\text { Number of } \\
\text { answers }\end{array}$ & Distribution (\%) \\
\hline \multirow{3}{*}{ Inswer } & Yes & 27 & $42,2 \%$ \\
\cline { 2 - 4 } & No & 37 & $57,8 \%$ \\
\hline \multicolumn{2}{|c|}{ Total: } & 64 & $100,0 \%$ \\
\hline
\end{tabular}

Source: own edition (2013)

strategy is mostly motivated by conforming to an external obligation (such as legal obligation or political will) instead of strategic planning and management driven by their own motivations. Conforming to this external obligation is already completed with the preparation of an economic program in most cases. After all, the results also indicate the lack of strategic management activities.

Afterwards, we tried to gather information about the frequency of revising strategic plans. The two basic criteria regarding planning are flexibility and realism, which both have to be present during the planning process. Plans must be reviewed continuously in order to see whether the set objectives are still realistic, and the designed actions and action programs are viable, or briefly whether the plan is still feasible. In order to make if feasible, the foreseen impacts of environmental changes considered on a wider level must be adapted, thus plans must be updated continuously. In this sense, the review and maintenance of plans - including strategic plans as well - has to be a continuous and frequent activity, otherwise the basic criteria of flexibility and realism will not be realized in the process of planning. Experiences show that these two principles are not as much realized in the public sector. Only $37,5 \%$ of respondents said that the revision of plans is a frequent, annual duty, while in case of $32,8 \%$ it is implemented in every $2-4$ years. Another significant share, $20,3 \%$ is repre- sented by those who perform revision activities occasionally, on a non-regular basis. Nevertheless, $56,3 \%$ of local governments participating in the study are satisfied with the realization of long-term goals and initiations. Strategic planning in case of local governments - considering that the providing of services is both special and public - can only be efficient and serve the interest of the "public", if the strategic objectives as the foundation of strategic plans are elaborated and approved by the cooperation of all stakeholders (involved parties). Based on the empirical data that supports this study, there is only a low level of such cooperation of involved parties in case of local governments in Hungary (figure 4.), since out of all parties, only the participation of the mayor, the notary and financial-administration leaders are determinant in the process of elaborating the strategy. It is recommended to ensure the active participation and motivation of other stakeholders in the process of long-term planning.

\section{Results regarding the examination \\ of the relationship between the size of the local government and strategic planning practices}

According to our hypothesis, there is no link between the size of the government and the applied strategic planning habits and practices, therefore performing a segmentation based on size is unnecessary here. By this, we attempt to prove that "size" is irrelevant when analysing the planning system. This relationship was analysed with Chi-squared test. The assumed results have been confirmed by the performed statistical independence analysis. With the help of the SPSS program, we were seeking for the relation between the size of the local government and the application of formalized strategic planning and the tracking of strategic plans. The statistical analyses demonstrated a low level of relation when per- 


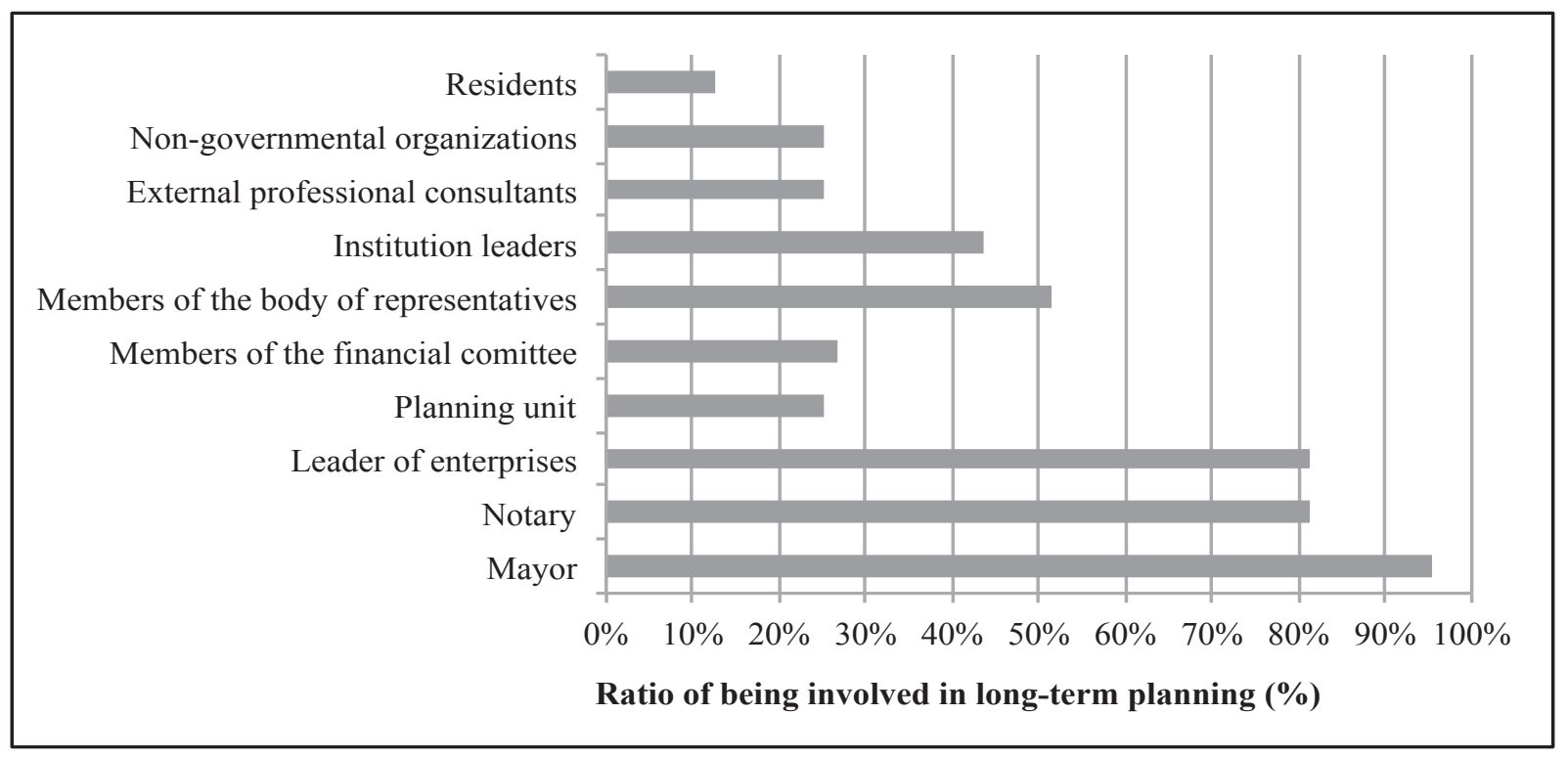

Figure 4.: Participants of preparing the strategic plan

Source: own edition (2013)

formed on a significance level of $22,1 \%$ with a 4,4 value of the test statistics, meaning that there is no statistical relationship between the size of the government and the application of formalized strategic planning in practice. There was also no relationship found between the tracking (monitoring) of the completion of strategic objectives within the entire length of the strategic period and the size of the government. The results demonstrate that this relationship exists on a significance level of $28,5 \%$ with a 3,792 value of the test statistics. We believe that the appearance of continuous monitoring implemented through the indicators of the plan objectives is linked to the application of formalized strategic planning, and is not dependent on the size.

\subsection{Short-term - annual-planning practices}

When analysing the short term - annual or shorter - planning practices, we come to a conclusion - detailed results are illustrated in annex no. 1. - that due to the regulations on the planning of governments, the preparation of the annual budget is most frequently applied as the primarily financial plan. The preparation of a liquidity plan is also typical, with a cumulated average of 77 percent, the high proportion of which can also be explained by the effective regulations prescribed by the law. ${ }^{7}$ The preparation of plans regarding cash flow, purchase, maintenance, risk management, resource or other short-term plans represent an unsubstantial percentage, since none of the aggregated average proportions regarding short term plans exceeds 40 percent. The lowest ratio, with an average of $25 \%$ is found in case of the preparation of cash flow. These comprehensive statements are valid when examining governments separately by their size. It is also important to see that $53 \%$ of large governments prepare risk assessment and planning, which might be explained by the large scale investments they have realized, and risk assessment and return calculations that are brought forward by the financing of EU investments and renovations.

As a summary, the emphasis of short-term planning is on the preparation of the annual budget and the planning of liquidity. Throughout the analysis we aspired to see the exact number of the different type of plans that are applied in practice. According to the results, the analysed self-governments prepare " 5 types of plans" in most of the cases $(23 \%)$, followed by " 4 types of plans" (in 17\%) as the second most frequent practice. When considering the number of mandatory plans, these results also demonstrate that local governments apply planning primarily with the objective to conform to legal obligations, and it is less triggered by their own motivations or management approach. All of this confirm our previous statements. The implementation of planning activities driven only by external forces contradicts the presence of strategy-driven management.

Regarding the planning of the annual budget as the most frequently prepared annual plan, the analyses has covered the examination of the methodologies as well, in particular in the form of multiple choice, yes or no and open questions about the methodology of the planning of the budget.

Amongst other issues, we have analysed the proportion of the practical application of planning techniques used in the preparation of the budget of local governments being included in the sample, and thus the level of its spread in practice. Respondents have been asked to distribute $100 \%$ amongst the major methods of budget planning, based on the frequency of

${ }_{7}$ Besides the preparation of the annual budget plan, the Áhtv. includes a brief note on the obligation of preparing a liquidity plan. [see Áhtv. 78.§ (2)] 


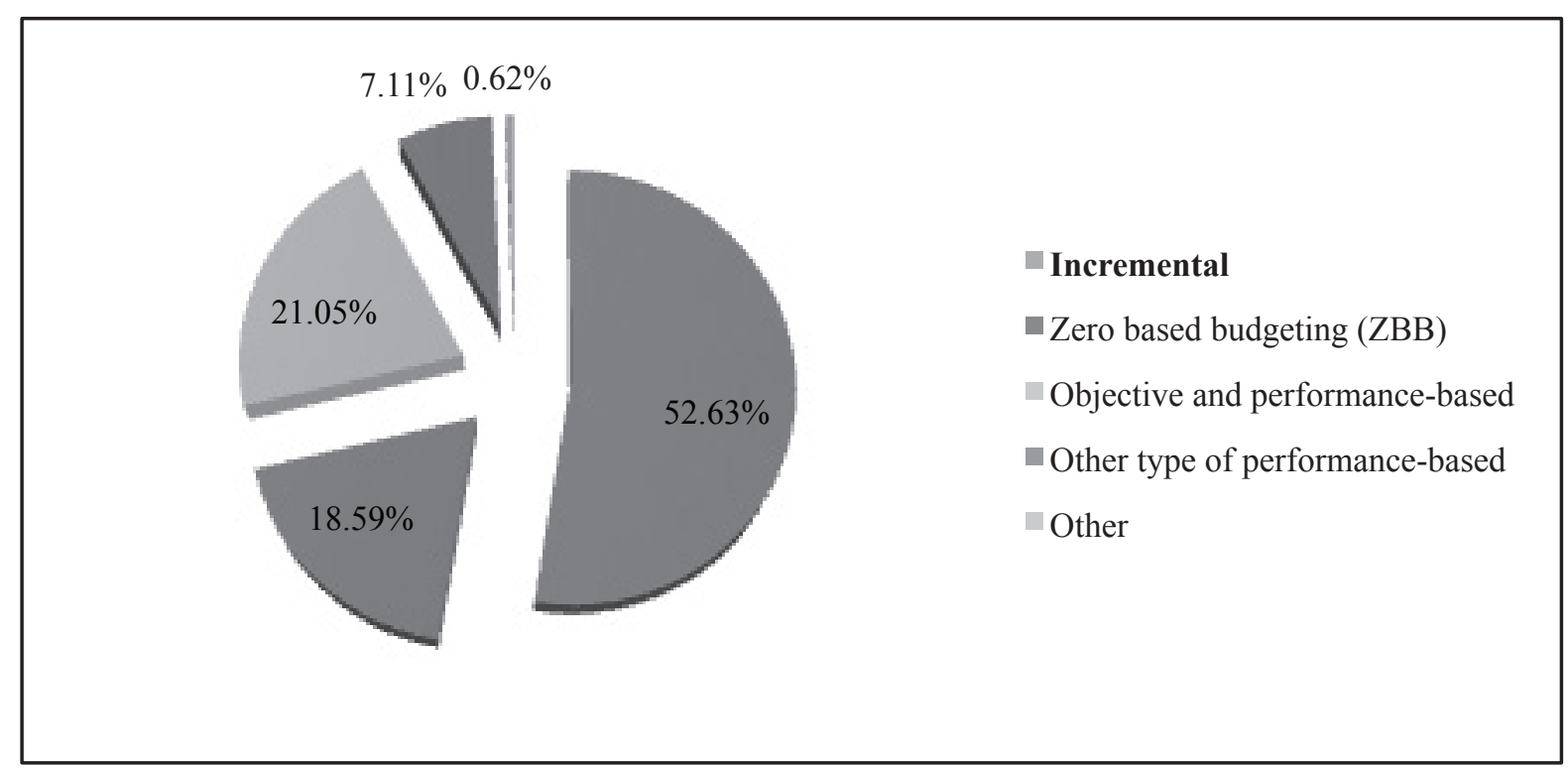

Figure 5. The proportion of the application of budget planning methods in practice

Source: own edition (2013)

their application in practice. The results of the analysis are illustrated by figure 5 .

Based on the literature about budget planning, the most urgent and obvious fields of the improvement of planning systems are the renewal of the technology of the annual budget planning and the decrease of the dominance of incremental budget planning techniques and its differentiated application by the type of tasks. The statements of our theoretical research was confirmed by the empirical results of our study, since $51,6 \%$ of involved parties believe that budgetary planning is characterized by a basic approach, which has to be changed in the future. As it is demonstrated by figure 5., when considering the estimations about expenditures on mandatory tasks, the majority of local governments included in the sample, $52,63 \%$ of them apply incremental budget planning techniques, and the second most frequently used methods are objective and performance based (program) techniques with a ratio of $21,05 \%$. The ZBB procedure is applied in case of an average of $18,59 \%$ of the local governments included in the sample. Within this group of questions, respondent governments applying objective and performance based planning methods were asked to appoint the tasks affected by program planning. By summarizing the answers, the most frequent tasks were the followings:

- settlement development,

- occasional projects, EU tenders,

- investment and renewal expenditures,

- residential old people's home care,

- maintenance,

- mandatory public work planning,

- sports,

- basic health care services,

- social expenditures.

Out of the listed tasks, program based budget planning methods and approaches are used most often in case of settle- ment development and investment and development related tasks.

When asked "if you do not apply program based budget planning techniques, do you plan to use it in the future?", the vast majority of respondents, $73,7 \%$ said no.

The questionnaire analysis therefore confirms the conclusions drawn from literature, which considers incremental budget planning to be the most popular planning method of local governments in Hungary. The results also testify our hypothesis that various budget planning techniques have to be differentiated to fit the task to be performed. Based on this hypothesis we also aspired to see how involved parties would differentiate budget planning methods amongst all mandatory tasks of local governments specified by the law in force. The following planning method options were offered

1. Incremental planning method

2. Zero based planning method

3. Program budget planning

4. Other

Other methods have not been specified by respondents, therefore the summary includes only the result of a choice from the three major methods. The summary of answers are included in annex number 2.

By summarizing the results, it is obvious that respondents believe the incremental planning technology to be the most efficient one to be applied with the majority of the government's tasks, and they only consider the planning of budget expenditures within the frame of a program structure to be better in case of settlement development, cultural services and sports, youth and nationality related issues. The zero-based planning method was not selected as a frequently applicable method by any of the participants. It is interesting that regarding the field of kindergarten and social care services and child protection, the ZBB method is preferred by respondents instead of program budgeting. These results reflect on a contradiction com- 
pared to results of the previous analysis, since they show that except for a few examples, those who are involved in planning are completely satisfied with having an incremental planning and they believe it to be the best method for allocating the budget amongst tasks.

\subsection{The future of the planning system from the viewpoint of stakeholders}

In order to provide a comprehensive evaluation of the planning system, we have composed 8 statements, which had to be evaluated on a scale from 1 to 3 . The options for grading were 1 - not true, 2 - true, but does not require modification and 3 - true and requires modification. The statements to be evaluated were the followings:

1. The incremental approach is dominant in case of the planning of the budget

2. Short-term plans support the implementation of long term plans

3. We consider the impacts of long-term goals on the budget when compiling the annual budget.

4. The significance of plans according to the order of subfunctions is low.

5. An annually repeated budget planning activity is dominant in the planning practice.

6. An institution-oriented planning is preferred instead of program planning.

7. The planning system fails to ensure transparent administration and the balance between the public duties to be performed (expenditures) and resources of financing (revenues).

8. The preparation of plans is basically motivated by having to complete various legal obligations.

The processed results are presented in details in annex number 3 .

By summarizing the results of the submitted answers it is obvious that there are only two scenarios when respondent governments feel that a change would be necessary, in case of the first statement - the incremental approach is dominant with the planning of the budget - and the seventh one - the planning system fails to ensure transparent administration and the balance between the public duties to be performed (expenditures) and resources of financing (revenues) - rating option "number 3" was dominant, with a ratio of $51,6 \%$ and $43,8 \%$. Regarding the remaining six statements, respondents admitted that the statement is true, yet they felt it does not require any modification or improvement in the future. Surprisingly, none of the statements received the answer " 1 ". These results project that those who are responsible and involved in the operation of the planning system at local governments are not open towards the innovation of the planning system. We believe that stakeholders are afraid of innovation because it is recommended to perform an efficiency screening on the planning process as the first step of development, which might imply the risk of reduction within certain elements and scope of duties of the process (lean approach), which might also re- sult in the reorganization or even the termination of the scope of duty in question.

With the last round of questions in the survey we attempted to examine the intention of further developing the planning system, the potential fields regarding the innovation of the planning system and also those recommended by governments, within the frame of multiple choice questions.

The introductory question investigated whether respondents "plan to improve the planning system in the near future". We have received favourable answers, as the development of the planning system is included in the short term objectives in the majority of the cases, which is $59,4 \%$ of respondents. The majority of respondents marked "three" - in 20,3\% - or "four" - in 18,8\% - fields for development. According to the answers summarized in table 2., key fields for the innovation of the planning system from the perspective of stakeholders are the establishment and improvement of the strategic planning process - in $65,8 \%$ - and the development of the budgetary technique, shifting it towards an objective and performance based planning - in $71,1 \%$. The majority has not preferred the remaining fields of development, or do not feel that these fields require improvement. Respondents had the opportunity to add further fields besides the listed fields for development under the category "other", however they have not submitted any new fields here.

\section{Conclusions}

We believe that planning systems must be strengthened in the future both regarding long-term and short-term planning, irrespective to the size of the government. Prior to the first step of development we must answer the basic question "what

Table 2. Opinion of local governments on the fields of innovation of the planning system

\begin{tabular}{|l|c|}
\hline \multicolumn{1}{|c|}{ Field for innovation } & $\begin{array}{c}\text { Proportion } \\
\text { of those who } \\
\text { said "yes" }\end{array}$ \\
\hline $\begin{array}{l}\text { The establishment and improvement of the process } \\
\text { of strategic planning }\end{array}$ & $66 \%$ \\
\hline $\begin{array}{l}\text { The strengthening of the strategic role of the economic } \\
\text { program within the frame of strategic planning. }\end{array}$ & $40 \%$ \\
\hline $\begin{array}{l}\text { Improvement of the budget planning technique towards } \\
\text { objective and performance based planning. }\end{array}$ & $71 \%$ \\
\hline $\begin{array}{l}\text { The elaboration/improvement of a system of indicators } \\
\text { measuring the realization of plans. }\end{array}$ & $26 \%$ \\
\hline $\begin{array}{l}\text { Establishment/improvement of a regular reporting system } \\
\text { towards the leaders. }\end{array}$ & $37 \%$ \\
\hline $\begin{array}{l}\text { Establishing an operational (causal) relation between long } \\
\text { term plans and the annual budget. }\end{array}$ & $47 \%$ \\
\hline Making the planned numbers more substantiated. & $34 \%$ \\
\hline $\begin{array}{l}\text { Strengthening the communications of plans, objectives } \\
\text { towards all members of the organization. }\end{array}$ & $26 \%$ \\
\hline $\begin{array}{l}\text { Establishing strategic and performance management } \\
\text { closely linked to planning. }\end{array}$ & $0 \%$ \\
\hline Other & \\
\hline
\end{tabular}

Source: own edition (2013) 
do we expect from planning". The right answer might be that the benefit measurable throughout the implementation of plans should be in accordance with the expectations of "stakeholders". Benefit in this sense equals the impact (outcome) on stakeholders - also being set amongst the preliminary objectives.

\section{The weakest points}

of the planning system according to the results

of the empirical research are:

- The preparation of plans are basically motivated by having to conform to various legal obligations, instead of being triggered by self-interest and management motivation. The compulsory nature of planning is also reflected by the low number of the various plans prepared, the lack of a strategic management and also by the excessive application of the incremental budget planning method which is regarded to be outdated.

- The planning system fails to ensure transparent administration and balance between the public services to be performed (expenditures) and resources of financing (revenues).

- An annually repeated budget planning activity is dominant in the planning practice. As a natural consequence, the operation, and finally the performance of public services is determined by the past and not by the future.

- The incremental approach is dominant in case of the planning of the budget.

- An institution-oriented planning is preferred instead of program planning.

- The presence of "ungovernable" or "uncontrollable" expenditures is inevitable, the only question is their proportion to the whole of expenditures. [Sisa-Szabó, 2013]

\section{Comprehensive suggestions on innovation regarding the planning system:}

- The strengthening of a strategic approach and strategic management, besides transforming strategic planning and analysing methods to be adaptable for local governments. Within this frame, the strengthening of the strategic role of the economic program. A Balanced Scorecard prepared for each program is the best method to support the completion of objectives set in strategic plans, and thus strategic management activities. Besides the application of BSC, we recommend the continuous implementation of complementary methods such as the SWOT, EFQM and Benchmark methods. With the help of these methods, it is possible to operate a complex strategic planning-analytic-decision supporting system within the frame of strategic controlling.
- The renewal of the budget planning technique, its differentiated application for each task and shifting towards objective and performance based budget planning. Task financing requires planning on a task level, the management of tasks by the cost bearer and the gathering of expenditures - and if possible, of revenues - by tasks.

- Linking strategic plans with the annual budget, the establishment of a measurable causal relation system. The imprints of the strategy are reflected by the preferences of the expense side in annual budgets. The measurability and traceability of the realization and completion of the causal relation and strategic objectives (figures) in the annual budget is supported by the complex strategic - tactical and budgetary planning system established within a program structure. Program structures improve the transparency of plans and support the system of task financing as well, since a particular program actually implies a task to be performed. ${ }^{7}$

- The establishment of an integrated tracking system of indicators for measuring the completion of plans. When elaborating these indicators, the peculiarities of the operation and administration of governments must be considered in order to create indicators that reflect these appropriately and accurately. On one hand, these might rely on the database received from the budgetary accounting system, and also from the "new" financial accounting information system (the complex accounting information system of the government in total).

- The operation of the whole of the planning system within the frame of a controlling system. It might be successfully adapted to fit in the public sector as well, conserving the basic functions and tools of controlling.

- The establishment of a cooperative planning system with the involvement of a wider range of stakeholders (e.g.: local enterprises, other administration organizations, non-governmental organizations, residents). This basic expectation is also defined by the public management philosophy also known as "Governance". Public hearings organized by local governments might provide an excellent opportunity for this, which must be well promoted in advance, in order to be able to deliver all the necessary information to stakeholders in due course.

\section{Prospective research trends:}

- A further verification by empirical research of the presumption that local governments adopting strategic planning enjoy comparative advantages on the long term (compared to other municipalities with similar circumstances, but operating without an actual strategy) is also being advocated in the dissertation.

- Involving local governments open-minded for further development, a programing method based on strategic

${ }^{8}$ Further details about the concept, structure and application benefits of the so-called program-based budget planning are described in the study of Báger [2006]. 
planning could be tested experimentally, by means of involving certain governmental functions, respectively.

- For further verification of the propositions formulated in the study, the advantages of controlling should be examined aiming to reveal specific municipal features in a research project performed among local governments already applying the method. Subsequently, the publication of experimental results gained in the research revealing the supportive role of the controlling in planning, could provide useful and instructive knowledge to experts concerned.

\section{Summary}

The study aims to reveal the main conclusions of the empirical study performed among local governments in Hungary, regarding their planning practices with a comprehensive approach. The primary research was conducted in the first quarter of 2013, in the framework of which the interviewed municipalities were requested to fill out the relevant fields of a questionnaire on a voluntary basis. The primary purpose of the survey was to determine if any formalized strategic and operative planning methods are actually being implemented in the actual planning procedure of the given municipality. Based on the results of the survey and our empirical data gathered in course of the process, the study endeavors to analyze modern planning methods and identify the areas requiring substantial reform.

\section{Literature}

Báger G. [2006]: Programalapú költségvetés. Jellemző vonások, gyakorlati tapasztalatok. Pénzügyi szemle Vol. 51. 3. Issue. pp. 281301.

Báger G.-Vígvári A. [2007]: Államreform, közpénzügyi reform. Nemzetközi trendek és hazai kihívások. ÁSZ kutató Intézete. Budapest. p.149.

Báger G.-Kiss D.-Kovács R.-Vígvári A. [2010]: A nemzetgazdasági tervezés megújítása. Nemzeti igények, Uniós követelmények. ÁSZ Kutatóintézet. Budapest. p. 92.

Csanádi Á.-Tóth J. [2002]: Az önkormányzatok pénzügyei. 013/2002. Perfekt Kiadó. Budapest. p. 290.

Dunleavy P.- Margetts H -, Bastow S.-Tinkler J. [2006:] New Public Management Is Dead — Long Live Digital-Era Governance. Journal of Public Admistration Research Theory. 16(3). pp. 467-494.

Faragó L. [1997]: Tervezéselméleti alapvetések. Tér és Társadalom Vol. 11. 1997/3. pp.1-15.

Faragó L. [2001]: Szeletek a tervezés mélyrétegeiből. Tér és Társadalom Vol. XV. pp. 11-24.

Farkas S. (ed.) [2004]: Költségvetés tervezés, gazdálkodás, beszámolás, ellenőrzés. Saldo Kiadó. Budapest. p. 397.

Fónagy Árva P.-Zéman Z.-Majoros Gy. [2003]: Értékmérési módszerek vizsgálata. Pénzügyi Szemle Vol. 48. 4. Issue pp.380-403.

Győrffi D-Vígvári A. (szerk.-lektorok) [2009]: A közpénzügyek nagy kézikönyve. Complex Kiadó. Budapest. p. 1115.
Hall D. [2012]: Re-municipalising municipal services in Europe. http://www.psiru.org/sites/default/files/2012-11-Remun.docx Download: 19.03.2013.

Hood C. [1991]: A public management for all seasons? Public Administration, 69(1) Spring.

Hunyadi L.-Vita L. [2002]: Statisztika közgazdászoknak. KSH. Budapest. p. 770.

Koháriné P.E. [2011]: Államháztartási ismeretek. Perfekt Kiadó. Budapest. p. 309.

László Cs. [1994]: Tépett vitorlák. Az államháztartásról közigazgatási és jogi szempontból. AULA Kiadó. Budapest. p. 363.

László Cs. [2012]: The State as a Public Service Provider - Rewised. Budapest Business School Science Almanach.

Lóránt Z. [2010]: Utak és tévutak -tények, adatok a helyi önkormányzatok gazdálkodásáról. Pénzügyi szemle Vol. 55. 3. Issue pp. 622-640.

Magyary Z. [1923]: A magyar állam költségvetési joga. A ,STUDIUM” bizománya.

Pollitt C-Bouckaert G. [2011]: Public Management Reform: A Comparative Analyis - New Public Management. Governance, and the Neo-Weberian State. 3rd Ed. Oxford UP.

Sisa K. [2013]: Kutatási kérdőív az önkormányzatok komplex tervezési folyamatának felmérésére. Budapest.

Sisa K.-Szabó Sz. [2013]: Települési önkormányzatok tervezési rendszerének a jövője az érintett önkormányzati szereplök szemszögéből. Erdei Ferenc Tudományos Konferencia. 2013. szeptember 5. Gazdálkodás és menedzsment tudományos konferencia. „Környezettudatos gazdálkodás és menedzsment”. II. kötet. Kecskemét. ISBN 978-615-5192-21-0 pp. 563-568.

Sivák J.-Vígvári A.: [2012]: Rendhagyó bevezetés közpénzügyek tanulmányozásába Complex Kiadó. Budapest. p. 261.

Szúcs I. (ed.) [2002]: Alkalmazott statisztika. Agroinform Kiadó. Budapest. p. 551.

Vígvári A. [2002]: Közpénzügyek, önkormányzati pénzügyek. KJK. Kerszöv Kiadó. Budapest. p. 380.

Vígvári A. [2009]: Pénzügyi kockázatok az önkormányzati rendszerben. ÁSZ kutató Intézete. Budapest p. 73.

Vígvári A. [2011]: Önkormányzati pénzügyek. Hazai kihívások és nemzetközi példák. ÁSZ kutató Intézete. Budapest. p. 114.

Warner M. E. [2008]: Reversing privatization, rebalancing government reform: Markets, deliberation and planning. Policy and Society, 27(2). pp. 163-174.

Warner M. E. [2010]: The Future of Local Government: TwentyFirst-Century Challenges. Public Administration Review 70 pp. 145-147.

Warner M. E. [2012]: Privatization and urban governance: The continuing challenge of efficiency, voice and integration. Cities, 29. pp. 38-43.

2011. évi CXCV. törvény az államháztartásról

2011. évi CLXXXIX. törvény Magyarország helyi önkormányzatairól 368/2011. (XII.31.) évi kormányrendelet az államháztartásról szóló törvény végrehajtásáról

249/2000. (XII. 24.) Kormányrendelet az államháztartás szervezetei beszámolási és könyvvezetési kötelezettségének sajátosságairól

4/2013. (I.11) Kormányrendelet az államháztartás számviteléről

2000. évi C. törvény a Számvitelről 